\title{
Smoldering Remediation of Coal-Tar-Contaminated Soil: Pilot Field Tests of STAR
}

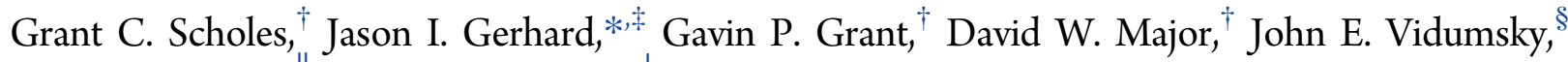
Christine Switzer, "and Jose L. Torero ${ }^{\perp}$

\author{
${ }^{\dagger}$ Savron, 130 Stone Road West, Guelph, ON, Canada N1G $3 Z 2$ \\ ${ }^{\ddagger}$ Department of Civil and Environmental Engineering, The University of Western Ontario, London, ON, Canada N6A 5B9 \\ ${ }^{\S}$ DuPont Corporate Remediation Group, Chestnut Run Plaza Building 730, Wilmington, Delaware 19805, United States \\ "Department of Civil and Environmental Engineering, University of Strathclyde, 75 Montrose Street, Glasgow G1 1XJ, United \\ Kingdom \\ ${ }^{\perp}$ School of Civil Engineering, University of Queensland, Brisbane 4072, Australia
}

\section{Supporting Information}

\begin{abstract}
Self-sustaining treatment for active remediation (STAR) is an emerging, smoldering-based technology for nonaqueous-phase liquid (NAPL) remediation. This work presents the first in situ field evaluation of STAR. Pilot field tests were performed at $3.0 \mathrm{~m}$ (shallow test) and $7.9 \mathrm{~m}$ (deep test) below ground surface within distinct lithological units contaminated with coal tar at a former industrial facility. Self-sustained smoldering (i.e., after the in-well ignition heater was terminated) was demonstrated below the water table for the first time. The outward propagation of a NAPL smoldering front was mapped, and the NAPL destruction rate was quantified in real time. A total of $3700 \mathrm{~kg}$ of coal tar over 12 days in the shallow test and $860 \mathrm{~kg}$ over 11 days in the deep test was destroyed; less than $2 \%$ of total mass removed was volatilized. Self-sustaining propagation was relatively uniform radially outward in the deep test, achieving a radius of influence of $3.7 \mathrm{~m}$; strong permeability contrasts and installed barriers influenced the front propagation geometry in the shallow test. Reductions in soil hydrocarbon concentrations of $99.3 \%$ and $97.3 \%$ were achieved in the shallow and deep tests, respectively. Overall, this provides the first field evaluation of STAR and demonstrates that it is effective in situ and under a variety of conditions and provides the information necessary for designing the full-scale site treatment.
\end{abstract}

\section{INTRODUCTION}

Coal tar and creosote (composed of various coal-tar fractions) are a class of nonaqueous-phase liquids (NAPLs) that consist of a complex mixture of aliphatic and aromatic compounds produced as a by-product of historical manufactured gas plant operations and blast-furnace coke production. ${ }^{1-3}$ Coal tar is classified as a human carcinogen, ${ }^{4,5}$ and over 1500 coal-tar waste sites were listed by the US Environmental Protection Agency (EPA) in 1984, ${ }^{5}$ many of them near or within heavily populated areas.

There are few commercially available remedial technologies capable of rehabilitating coal-tar- and creosote-contaminated sites to applicable standards. ${ }^{6}$ This is because these contaminants exhibit a combination of physical and chemical properties that make them unsuitable for most available treatment processes. They exhibit densities on the order of 1010 to $1100 \mathrm{~kg} / \mathrm{m}^{3}$ making them denser than water (i.e., DNAPLs), meaning that the water table is not a barrier to downward migration. Their relatively high viscosities (20 to
$100 \mathrm{cP})$ promote continued migration over large lateral distances and prolonged periods of time after release (e.g., refs 1 and 7) and make them resistant to removal via pumpingbased technologies. In addition, coal tar and creosote are composed of both large aromatic and long-chain hydrocarbons, which are resistant to biodegradation. ${ }^{9}$ Moreover, due to their high boiling points, they are unsuitable for technologies such as soil vapor extraction ${ }^{8}$ that depend on volatilizing the in situ mass. Thermal remedies such as in situ thermal desorption may be used on coal tar sites in two modes: low temperature (up to $100{ }^{\circ} \mathrm{C}$ ), which volatilizes lighter compounds ${ }^{10,11}$ but leaves heavier components behind, or high temperature (greater than $\left.100{ }^{\circ} \mathrm{C}\right),{ }^{12}$ which requires significant energy input; ${ }^{13}$ in all three cases, the goal is to drive the majority of mass into the vapor

Received: June 30, 2015

Revised: October 25, 2015

Accepted: November 2, 2015

Published: November 2, 2015 


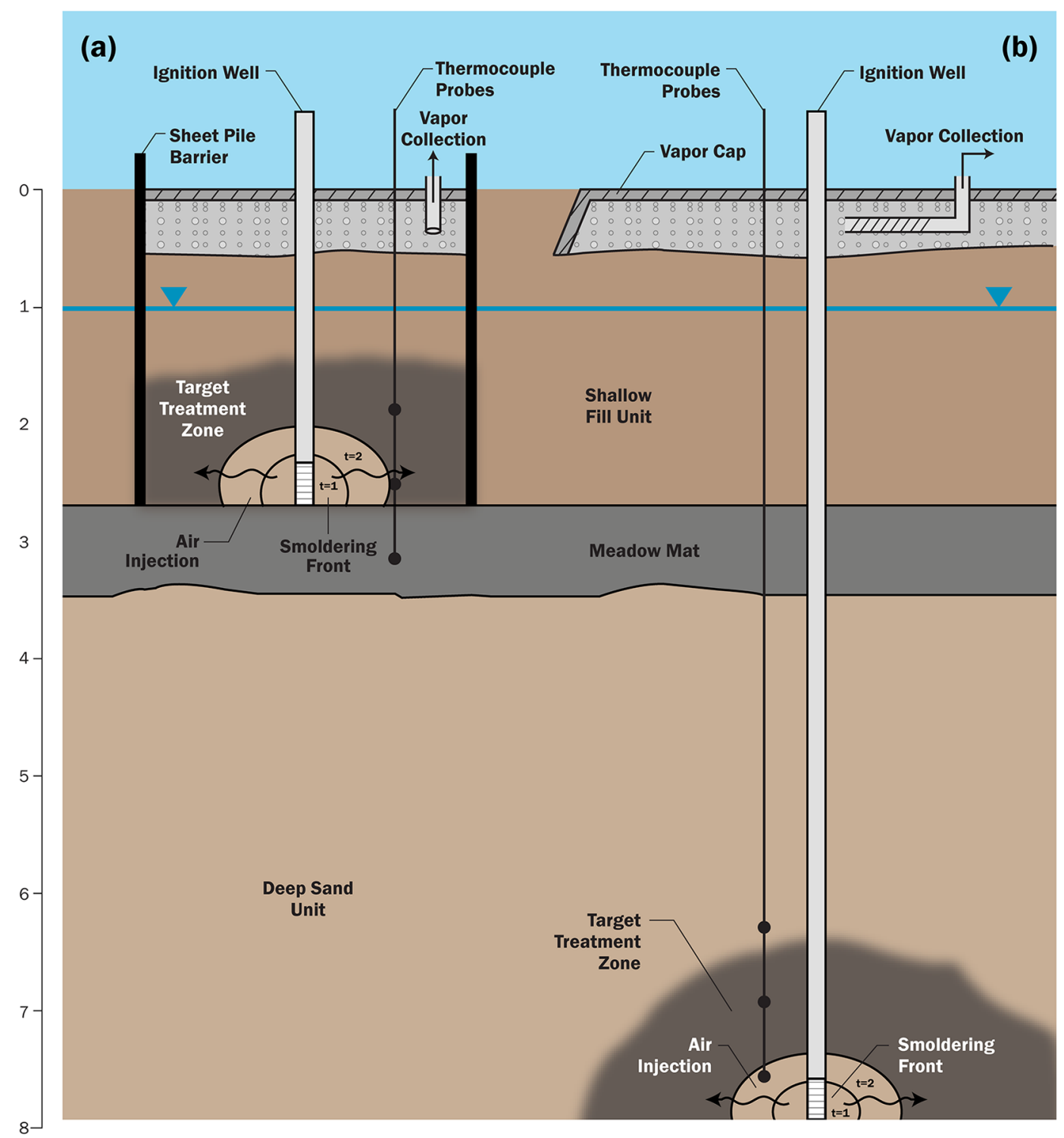

Figure 1. Schematic cross-section of shallow (a) and deep (b) field-test cells. The shallow field test consisted of ignition wells installed to the base of the shallow-fill unit in a test cell contained by a sheet pile barrier. The deep field test consisted of an ignition well installed in the deep-sand unit with no sheet pile barrier. Both field tests were initiated under fully saturated conditions (i.e., below the water table). Hemispherical propagation of the smoldering front is shown outside the ignition well screens: $t=1$ coincides with the preheated zone and onset of smoldering, while the front location at $t=2$ represents self-sustained smoldering with only air injection.

phase for collection and treatment at the surface. In the subset of cases where site recovery is attempted, coal-tar source areas are usually treated via excavation and disposal or incineration. ${ }^{6}$

Recently, the concept of NAPL remediation via smoldering combustion was introduced $^{6,14}$ as self-sustaining treatment for active remediation (STAR). Smoldering is a combustion process that occurs on the surface of a condensed (i.e., solidor liquid-phase) fuel, converting organic material into primarily heat, carbon dioxide, and water. ${ }^{15}$ Burning charcoal in a barbeque is a familiar example. Smoldering has been well documented for solid porous materials (e.g., fibrous materials, coal, and polyurethane foam). ${ }^{15-19}$ Laboratory studies first demonstrated that smoldering of an organic liquid (i.e., NAPL) embedded within an inert porous matrix was possible. ${ }^{6,20}$ That work also demonstrated that the reaction would continue in a self-sustaining manner (i.e., continue in the absence of external energy input following a one-time, local ignition) and would destroy the NAPL as long as an oxidant (e.g., oxygen in air) and fuel (NAPL) were in sufficient quantity. The practical result is a hot, self-sustaining smoldering "wave" that propagates from the ignition point through the contaminated soil in the direction of air flow. This reaction wave, while relatively thin in the direction of travel (i.e., from thicknesses of centimeters to tens of centimeters), is composed of a complex set of pyrolysis (i.e., endothermic, thermal breakdown) and oxidation (exothermic, converting carbon compounds to $\mathrm{CO}_{2}$ and $\mathrm{H}_{2} \mathrm{O}$ ) reactions. Although the majority of NAPL removal in smoldering is via destruction through oxidation, a fraction of the NAPL can be volatilized during pyrolysis reactions and also through the heat wave that arrives (via convection and conduction) in advance of the smoldering wave.

A series of laboratory column experiments demonstrated remediation via smoldering destruction for synthetic mixtures of coal tar in sand and field-obtained coal-tar-contaminated soils. ${ }^{6}$ These experiments characterized the conductive ignition method required to initiate the smoldering reaction, the 
ignition protocol for coal tar mixtures (i.e., heat and air fluxes required to initiate smoldering), and the controllability of the smoldering process. A suite of column experiments demonstrated that (1) a minimum NAPL content was required to support self-sustaining smoldering; (2) the velocity of the smoldering front, and thus the mass destruction rate, was linearly related to the air injection rate; and (3) water content up to $75 \%$ of pore space reduced peak temperatures but did not impede the self-sustainability of the reaction for both coal-tar and crude-oil NAPLs. ${ }^{14}$ These findings are consistent with smoldering research in other contexts, such as fire safety studies of solids such as dust, coal, and foam, ${ }^{17,18,21-26}$ and in situ combustion for oil reservoirs. $^{27,28}$ In the benchtop studies, selfsustaining smoldering resulted in greater than $99 \%$ coal tar concentration reductions in soil., ${ }^{6,29}$ Similar results were observed for two experiments conducted with $1 \mathrm{~m}^{3}$ of material, a synthetic coal tar-sand mixture and a mixed oily waste, in a simple ex situ container. ${ }^{30}$ Under controlled conditions, the approach appears very promising.

However, all of the research on NAPL smoldering has been conducted using laboratory-scale columns or small ex situ drums or bins. STAR has never been assessed for treating NAPLs in the field. As a result, the ability to achieve ignition and propagate a self-sustaining smoldering front under real field conditions, in particular in situ and under water-saturated conditions, is unproven. Also, the relevance of the column test results to real applications is unknown. Moreover, the key metrics for designing a smoldering in situ site remedy are unknown, including the power requirements, rate of NAPL destruction, ultimate radius of influence for a single ignition well, chemistry of gaseous emissions, and soil treatment efficiencies. Furthermore, a methodology for field application has never been demonstrated; for example, the ignition method used in all previous tests (a conductive element embedded in the soil) is not practical for in situ applications.

This work presents the first in situ, pilot-scale field tests of smoldering remediation. It presents an evaluation of STAR's ability to remediate coal-tar NAPLs in the subsurface and beneath the water table at a former industrial facility in Newark, New Jersey (the "Site"). A total of two field pilot tests were conducted, one shallow and one deep, each in a different lithological unit at the site. The tests were designed to demonstrate the ability to initiate and maintain a self-sustaining smoldering combustion reaction in the subsurface and below the water table while quantifying peak temperatures, smoldering velocities, treatment rates, treatment efficiencies, emissions, the radius of influence of a well, and the energy requirement for ignition.

\section{MATERIALS AND METHODS}

Layout and Operation of Field Pilot Tests. A total of two pilot tests were conducted in the area of a backfilled lagoon at the site that was operated from the early 1900s until 1983. The area has been characterized through a series of borehole investigations. The lagoon was 2.5 to $3.5 \mathrm{~m}$ deep and was used to dispose of coal tar and its by-products. The lagoon was closed in 1965 by backfilling with a heterogeneous mixture of sand, brick, and other construction materials (herein referred to as the "shallow fill unit"). Beneath this unit is a $0.3-0.6 \mathrm{~m}$ thick confining clay "meadow mat" layer. It is underlain by an alluvium unit, composed of medium-to-coarse sands up to $6 \mathrm{~m}$ thick (herein referred to as the "deep sand unit"). The water table at the site is approximately $1 \mathrm{~m}$ below ground surface (bgs, Figure 1a). Coal-tar DNAPL exists as a potentially mobile, highly saturated pool sitting upon the meadow mat and up to $1.3 \mathrm{~m}$ thick within the shallow fill unit. Coal tar is also present in the upper 4 to $5 \mathrm{~m}$ of the deep sand unit, likely resulting from discontinuities in the confining clay that have been observed in cores collected from the former lagoon area and potentially through the removal of the meadow mat during the excavation of the lagoons. Average hydraulic conductivities in the shallow fill and deep sand units are $6.8 \times 10^{-4}$ and $1.4 \times$ $10^{-4} \mathrm{~m} / \mathrm{s}$, respectively, although the deep sand unit appears much more uniform on the basis of observation of cores from each unit. Subsurface characterization of field sites presents a fundamental limitation to understanding any in situ study.

The two pilot tests were conducted between October 2010 and November 2012. The first test was conducted in the shallow fill unit and is referred to as the "shallow test". The shallow test was applied in a $6.0 \mathrm{~m}$ by $18.3 \mathrm{~m}$ (plan view) test cell constrained by sheet piling keyed into the underlying Meadow Mat to prevent adjacent coal tar migrating into the cell following the test (Figure 1a). The "deep test" was conducted in the deep sand unit below the same lagoon and adjacent to the shallow test cell, and was outside the sheet pile footprint (Figure 1b). Each test area had a centrally installed $5 \mathrm{~cm}$ diameter stainless steel well with a $30 \mathrm{~cm}$ long wire-wrapped (10 slot) screen that served as the ignition well for delivering heat and air. The shallow test used a hollow stem auger to install the well, with the bottom of the screen located at the base of the shallow fill unit at a depth of $2.7 \mathrm{~m}$ bgs (Figure 1a). The deep ignition well was installed with sonic drilling, with the bottom of the screen located $7.9 \mathrm{~m}$ bgs (Figure $1 \mathrm{~b}$ ). In both cases, the screens were located near the base of a significant coal-tar-contaminated interval as detected by borings.

Custom-built, removable, down-well electrical heaters were used to ignite NAPL adjacent to the ignition wells via convective heat transfer. The shallow and deep tests used 4.1 $\mathrm{kW}$ electrical resistance and $9 \mathrm{~kW}$ cartridge heating elements, respectively. This represents a completely novel smoldering ignition method that uses convection of heater air to ignite the NAPL immediately surrounding the well screen. The heaters were turned off following ignition (confirmed by the detection of combustion gases in collected vapors), and air injection flow rates were manipulated manually at the well to maintain and propagate the combustion front in a self-sustaining manner. Air was supplied by above-ground electric rotatory screw compressors (shallow test: Kobelco KNWA1-G/H; deep test: Sullair TSR-20-200). Air-injection flow rates were measured using rotameters (McMaster Carr panel-mount 2-20 SCFM) and Venturi flow meters (Venturi "V" series low-loss style, 11.5 " throat; brass) and injection pressures using pressure gauges (Dwyer SGY-D10522N). Injected pressures and flow rates were controlled using inline pressure regulators and gate valves located adjacent to flow elements. Air injection rates and pressures varied from 10 to $340 \mathrm{~m}^{3} / \mathrm{h}$ and 3.4 to $275 \mathrm{kPa}$, respectively, throughout the tests.

A vapor cap of gravel overlain with lean concrete was installed to collect and monitor combustion gases and vapors for both tests (Figure 1). The vapor cap for the shallow test extended to the sheet pile perimeter wall, whereas the deep test vapor cap was $15.3 \mathrm{~m}$ by $15.3 \mathrm{~m}$ (plan view). Vapors were collected under vacuum applied to the gravel layer by extraction blowers and treated via a series of vapor-phase granular activated carbon (GAC) vessels prior to discharge through a stack. Extracted vapors were collected during each test via an 

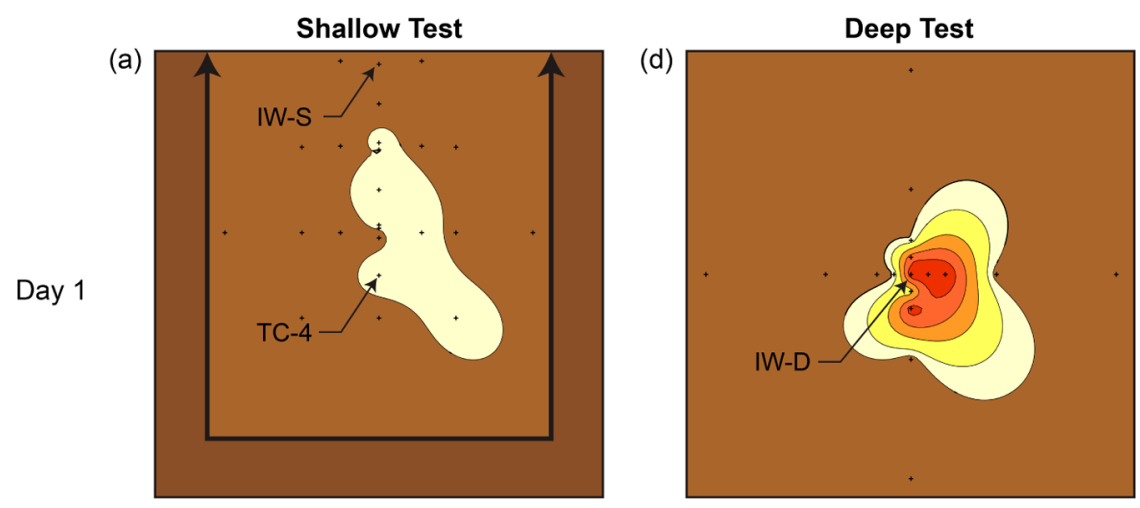

\section{Temperature}

$\left({ }^{\circ} \mathrm{C}\right)$
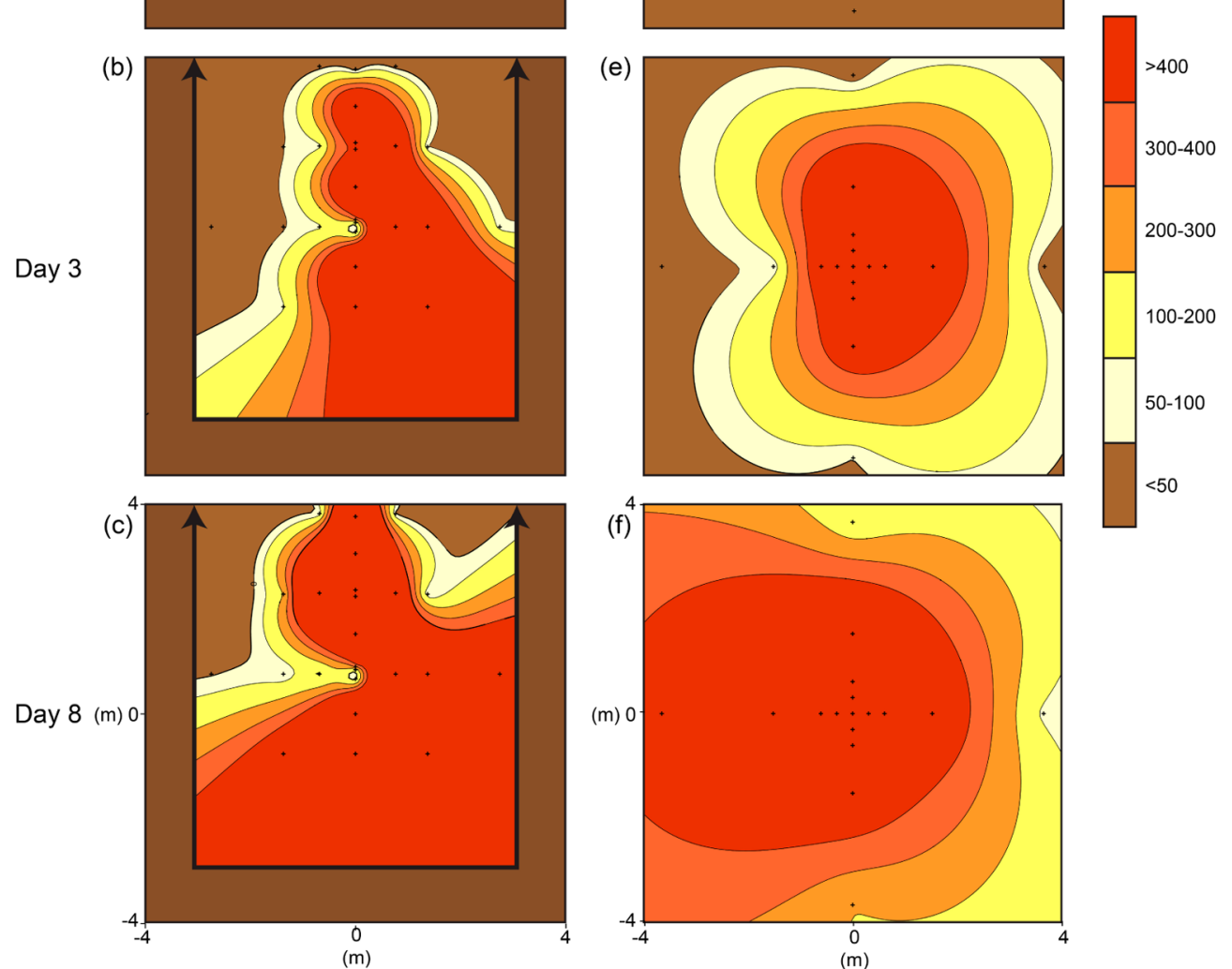

Figure 2. Maximum temperatures achieved at any depth following 1, 3, and 8 days of operation in the shallow (a-c) and deep (d-f) tests. Plot origins correspond to ignition origins. Thermocouple locations marked by a + symbol. Arrowed outline around the shallow-test cell represents the sheet-pile wall (continues out of view). Note that the maximum plotted temperature is above $400{ }^{\circ} \mathrm{C}$ to indicate combustion; peak temperatures in the shallow test reached over $1000{ }^{\circ} \mathrm{C}$, and in the deep test, they exceeded $600{ }^{\circ} \mathrm{C}$. Note that the figure does not show how temperatures rapidly cooled after the relatively thin combustion front passed through each thermocouple location.

automated sampling probe with a heated umbilical line (M\&C SP2000) and analyzed using a continuous emissions monitoring (CEM) system for carbon monoxide (CO, Thermo Fisher $-48 \mathrm{C}$ dual range), carbon dioxide $\left(\mathrm{CO}_{2}\right)$ and oxygen $\left(\mathrm{O}_{2}\right.$, Servomax, 1440) that were recorded every $30 \mathrm{~s}$ by a data acquisition system (Agilent 3890A multiswitch unit). Extracted vapor samples were also collected periodically via Summa canisters from sampling ports located before and after the GAC vessels. These samples were analyzed by commercial analytical laboratories for volatile organic compounds via the United States Environmental Protection Agency (USEPA) method TO-15. The velocity of the extracted vapors was measured a minimum of two times daily in the extraction piping using a digital handheld thermo-anemometer (TSI VelociCalc Plus).

Subsurface temperatures were measured using inconelsheathed type- $\mathrm{K}$ thermocouple probes installed via direct push drilling methods. The shallow test contained 166 measurement locations using a combination of multi- and single-depth subsurface thermocouples placed throughout the cell (Figures $2 \mathrm{a}-\mathrm{c}$ ) at depths of 1.5, 1.8, 2.1, 2.4, and $2.6 \mathrm{~m}$ bgs, with the greatest frequency of thermocouples placed near the ignition well. The deep-test thermocouple network consisted of 99 measurement locations using 16 multidepth (six-junction) subsurface thermocouples installed at the four points of the compass at radial distances of $0.3,0.6,1.5$, and $3.7 \mathrm{~m}$ (Figures $2 \mathrm{~d}-\mathrm{f}$ ), each with measurement points at $4.2,5.1,6.3,6.9,7.5$, and $8.1 \mathrm{~m}$ bgs, as well as three thermocouples installed in the ignition well boring. Temperature data was collected every $30 \mathrm{~s}$ throughout both tests using a data acquisition system (Agilent 3890A multiswitch with internal temperature calibration cell) and transferred daily to a Microsoft Access database.

Direct push-coring methods were used to collect pre- and post-test soil samples. A commercial laboratory was employed to analyze the samples to quantify coal-tar hydrocarbons by 
USEPA method 8015B for total petroleum hydrocarbons (TPH) prior to September 1, 2010 and thereafter, as prescribed by regulation, and equivalent data were obtained by the New Jersey Department of Environmental Protection (NJDEP) method revision 3 for extractable petroleum hydrocarbons $(\mathrm{EPH})$. Thus, in the shallow test, 15 pre- and 8 post-test samples were collected and analyzed for $\mathrm{TPH}$, while for the deep test, 8 pre- and 14 post-test samples were collected and analyzed for EPH.

Methods of Data Analysis. Following ignition, temperature measurements were used to infer the speed and propagation pattern of the combustion front. A sharp spike in temperatures from $200{ }^{\circ} \mathrm{C}$ to above $400{ }^{\circ} \mathrm{C}$ at a thermocouple indicated the arrival of the smoldering front; note that ignition of coal tar via STAR occurs between 200 and $300{ }^{\circ} \mathrm{C} .{ }^{20}$ The arrival times, combined with distance of the thermocouples from the ignition point, provided smoldering front velocity estimates. Estimating the evolution of the treated region in plan view was accomplished with the following procedure. The twodimensional temperature isosurface interpretations of the maximum achieved temperatures from each thermocouple location (at any depth) were generated using Kriging algorithms (Surfer, Golden Software). The shallow data set was compiled into 24 plan view locations (i.e., data points) from the southern half of the test cell only, and the deep data set was compiled into 17 plan view locations for the interpretations. A point Kriging method was used on the compiled temperature data sets with the test areas (approximated as an $8 \mathrm{~m}$ long by $8 \mathrm{~m}$ wide domain) represented by a 10000 node square grid ( $0.08 \mathrm{~m}$ spacing). Combustion zones were defined as Kriged regions exhibiting temperatures above $400{ }^{\circ} \mathrm{C}$.

The rate of coal-tar mass destroyed was estimated using the measured combustion gases, $\mathrm{CO}_{2}$ and $\mathrm{CO}$, and measured vapor-flow rates; method details are provided in the Supporting Information. This represents a unique ability to track, in real time, the rate of NAPL remediated in situ. The mass loss rate from volatilization was estimated by multiplying the sum of the concentrations of all individual volatile species detected in the Summa canister grab samples from the vapor extraction system by the volumetric flow rate of extracted vapor at the time the sample was collected. "Destruction and removal efficiency" (DRE) was defined as the ratio of the mass of contaminant destroyed in situ to the total mass removed through both volatilization and in situ destruction per unit time. "Remediation efficiency" was defined as the average percent concentration reduction (as TPH or EPH for the shallow and deep tests, respectively) in soil samples collected from combustion zones after STAR treatment to those collected before treatment.

The energy input required to treat a given mass of contaminated soil was quantified by dividing the "energy for ignition" by the mass of soil treated. The "energy for ignition" was defined as the energy applied to the heater (heater power multiplied by duration of operation) to achieve self-sustaining combustion; heater efficiency was neglected. The total mass of soil treated was estimated as the product of the plan view maximum radial extent of STAR propagation (radius of influence) and the thickness of soil treated, as identified from both the thermocouple data and pre- and post-treatment soil cores.

\section{RESULTS AND DISCUSSION}

Ignition and Smoldering Front Propagation. Ignition of a self-sustaining subsurface smoldering combustion reaction was observed following a period of preheating in both the shallow and deep tests. Smoldering combustion was confirmed when: (1) temperatures measured in the subsurface were higher than injected air temperatures (indicating an exothermic reaction); and (2) increases above baseline were observed in concentrations of combustion gases $\left(\mathrm{CO}_{2}\right.$ and $\left.\mathrm{CO}\right)$ in collected vapors. Initiation of smoldering combustion was observed within $24 \mathrm{~h}$ of heater startup in the shallow test and within $3 \mathrm{~h}$ in the deep test. The shorter preheating period for the deep test is the result of improvements in heater design. ${ }^{31}$ Upon confirmation of smoldering, the heaters were turned off, and only air injection was continued.

Figure 2 presents temperature isosurface interpretations of maximum achieved subsurface temperatures (for any depth) following 1, 3, and 8 days of operation for the shallow and deep tests. Heterogeneities were apparent in both tests but more pronounced in the shallow test. In the shallow test, the combustion front was observed to propagate a distance of 6.7 $\mathrm{m}$ from the ignition well (IW-S) to the southern portion of the test cell (to TC-4, Figure 2a) following a narrow path along the centerline of the cell. This propagation event, occurring at a depth of $2.4 \mathrm{~m}$ bgs (the height of the top of the screen in the ignition well) over a period of approximately $40 \mathrm{~h}$, followed a thin preferential pathway that was estimated to be less than 0.3 $\mathrm{m}$ thick on the basis of thermocouple density. This pathway was confirmed to be a trough of bricks within the fill layer when the cell was excavated following the test. Emergence of the combustion front at TC-4 is used as the combustion origin $(r=$ $0)$ and time $(t=0)$ in subsequent analysis of the smoldering front propagation (Figure $2 \mathrm{a}-\mathrm{c}$ ) because more typical (nonpreferential) radial expansion of the smoldering front through the fill started at this time. Figure $2 b$ shows that the combustion front had propagated to the southern and eastern boundaries of the test cell 3 days after emergence at TC-4. After 8 days, the combustion front had extended further north as well as reached the eastern extents of the test cell (Figure 2c) with a thickness of up to $1.1 \mathrm{~m}$ (at a measured depth of 1.5 to $2.6 \mathrm{~m}$ bgs) Air injection was terminated after decreases in temperature and corresponding decreases in combustion gas concentrations (down to ambient levels) were observed 2 days later, following approximately 10 days of operation.

In contrast to the shallow-fill test, the deep-sand test exhibited a more uniform combustion front propagation pattern immediately after ignition, as shown in Figure 2 (df). Thermocouple measurements showed steady and spatially uniform propagation of the combustion front in the alluvial sand over 8 days of self-sustaining smoldering. The test was terminated, by turning off the injected air, after 10 days when the combustion front had propagated beyond the extent of the monitoring network, leaving a treated zone of up to $3.7 \mathrm{~m}$ radius (centralized around the ignition well) with a thickness of up to $1.9 \mathrm{~m}$ (at a measured depth of 6.2 to $8.1 \mathrm{~m} \mathrm{bgs}$ ). A plot of confidence percentage contours of the Kriged values in Figure 2 reveals confidence levels of $85 \%$ and above within the primary combustion zones between the ignition wells and the outermost thermocouple locations (Figure S1).

The interpretations in Figure 2 show only the total extent of the smoldering front up to a given time, not the real-time distribution of temperature at the time specified in the figure. 

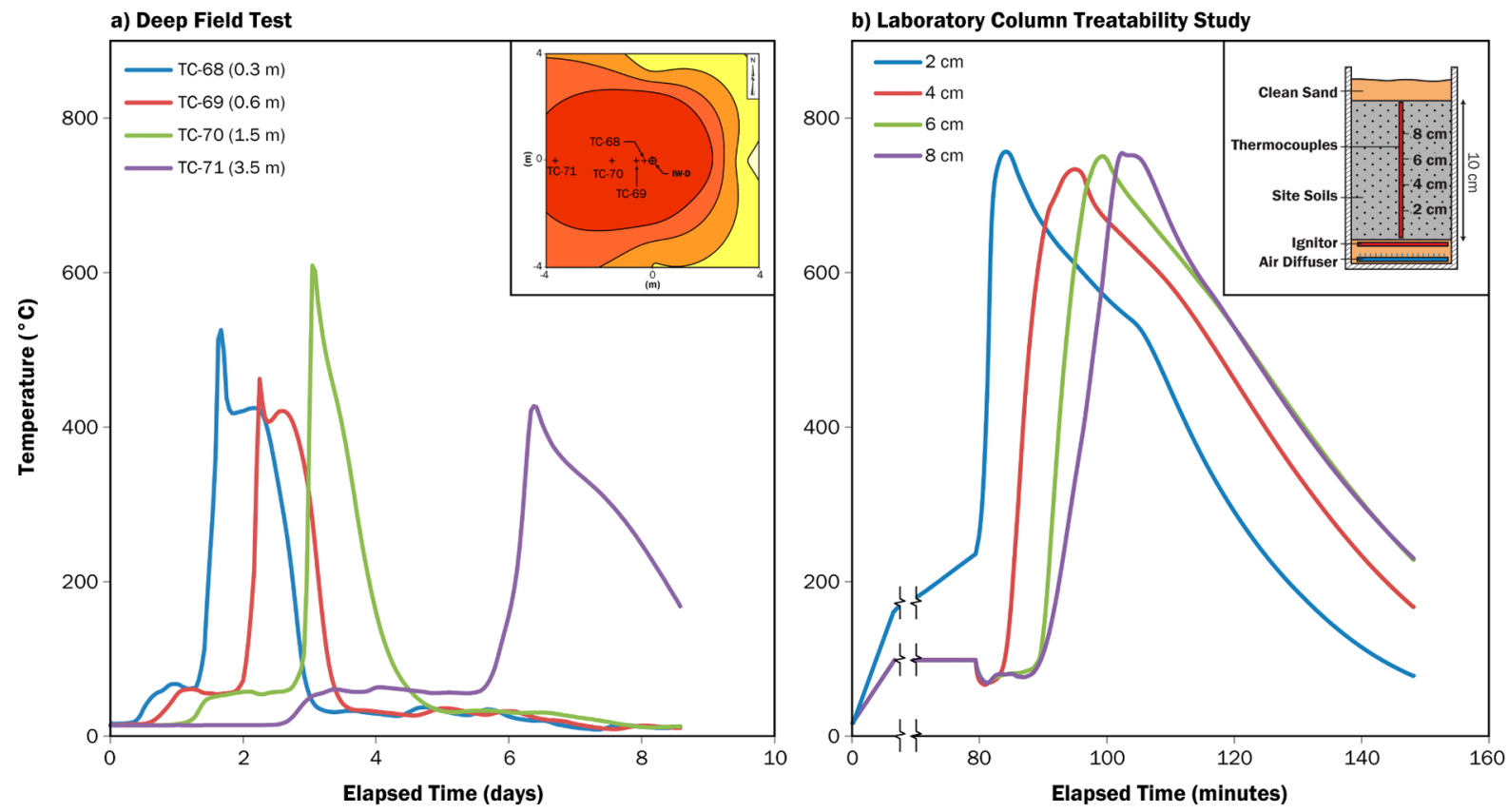

Figure 3. Temperature history trends for a single line of thermocouples in the deep-field test (a) and laboratory treatability study (b). Inset in (a) shows the thermocouple locations in plan view, while the inset in (b) is the laboratory column apparatus described fully elsewhere ${ }^{6,14}$ with the vertically oriented thermocouple locations.

The smoldering front is relatively thin in the direction of its velocity. As it propagates outward, released energy is transferred ahead to the unburned coal tar, and cooling occurs in the treated zone between the front and the air-injection well. This is illustrated in the temperature-history plot for one radial line of thermocouples in the deep test (Figure 3a); as the smoldering front reaches $3.5 \mathrm{~m}$ from the ignition point, temperatures between the $3.5 \mathrm{~m}$ thermocouple and the ignition point are all below $60{ }^{\circ} \mathrm{C}$. Such a series of crossing temperature-time plots and consistent peak temperatures is characteristic of a self-sustaining smoldering reaction. ${ }^{18}$

Similar behavior was observed in the STAR laboratory treatability study conducted using contaminated soil from the Site (Figure 3b). STAR treatability studies involve vertical, upward, smoldering propagation in steel columns (Figure 3a inset) following published procedures. ${ }^{6,14}$ The self-sustaining nature of the reaction is evident and was an important criterion for moving forward with the pilot field tests. It is not surprising that the peak temperatures $\left(\sim 750{ }^{\circ} \mathrm{C}\right)$ and the front propagation velocity $(1.1 \mathrm{~m} /$ day $)$ observed in the laboratory were higher than those observed in the field (quantified next). In both cases, the thermocouple accurately recorded the peak temperature; however, conditions were not identical. In particular, (i) the air flux in the field was likely significantly less than that applied in the laboratory (e.g., due to air compressor limitations, radial distribution, and decreasing pressure with distance from the injection well), and (ii) the water content in the field (below the water table) was significantly greater than in the laboratory (drained field sample). Laboratory tests have confirmed that peak temperatures are lower in conditions of higher water content (as this is a heat sink) and lower air flux (as this reduces the rate of heat release). ${ }^{14}$ This is the first time a STAR laboratory treatability test could be compared to in situ results and provides confidence that a determination of self-sustainability on the benchtop corresponds to field practice.
The peak combustion-zone temperatures observed in the shallow test ranged from 450 to $1200{ }^{\circ} \mathrm{C}$, while in the deep test, they were typically around $650{ }^{\circ} \mathrm{C}$. The difference in observed peak temperatures between the shallow and deep tests cannot be attributed to a single factor. Peak temperatures are sensitive to moisture content, properties of the porous medium, air injection rate, smoldering velocity, and degree of thermal equilibrium with the porous medium, ${ }^{6,14}$ all of which may be contributing at the field scale to the observed differences. Importantly, groundwater was not observed to prevent the initiation or propagation of a self-sustaining front, as the coal tar released sufficient energy on combustion to propagate a drying front ahead of the smoldering front (Figure 3).

For the shallow test, smoldering propagation velocities were calculated outward from TC-4 along a path that neglected the initial rapid and preferential smoldering through the bricks from the ignition well to TC-4. For the deep test, all thermocouples were used to calculate the front velocities. The calculated velocities were not normally distributed; therefore, the Wilcoxon Rank Sum (WRS) test (a nonparametric test) was used to compare the medians of the two populations. ${ }^{32}$ The calculated median velocities in the shallow and deep tests were $1.04(n=22, \mathrm{sd}=2.94)$ and $0.67(n=22$, $\mathrm{sd}=2.94) \mathrm{m} /$ day, respectively. A one-sided WRS test conducted at the $5 \%$ level of significance determined that the median velocity was greater in the shallow test than the deep ( $p$ value $=0.008)$. The higher calculated smoldering propagation velocity in the shallow test may be attributable to intrinsic permeability differences: it is on average more than four times higher in the shallow fill than the deep sand. Higher air velocities are directly related to higher smoldering front propagation velocities. ${ }^{14}$ Other factors that may contribute to velocity differences include different contaminant concentrations, different air pressures provided by the compressor over time, and the presence of the sheet piling in the shallow test. 
Mass Removal and Process Efficiency. The mass of coal tar destroyed in the shallow and deep tests were estimated to be 3700 and $860 \mathrm{~kg}$, respectively. Mass destruction rates ranged from 1 to $43 \mathrm{~kg} / \mathrm{h}$ in the shallow test and 1 to $7 \mathrm{~kg} / \mathrm{h}$ in the deep test. This calculation assumes complete capture of all generated combustion gases and is, therefore, a conservative estimate of the mass destroyed. Measurement error associated with the mass destroyed calculation is dominated by error in the air velocity measurement $(3 \%)$ and also affected by errors in the $\mathrm{CO}_{2}$ and $\mathrm{CO}$ measurements $(<1 \%)$. Some $\mathrm{CO}_{2}$ loss may occur due to dissolution in the overlying groundwater and soil moisture, which is not considered in the mass-destroyed calculations. The calculation is particularly conservative for the deep-test cell that had (i) no confining sheet pile to assist with vapor capture, (ii) an overlying confining layer (i.e., the meadow mat) that could force some gas outside the vapor capture zone, and (iii) a substantial thickness of overlying groundwater for the gases to traverse. Changes in combustion gas $\left(\mathrm{CO}\right.$ and $\left.\mathrm{CO}_{2}\right)$ concentrations versus time in extracted vapors from the shallow and deep tests reveal several interesting phenomena (Figures S2 and S3). First, they reveal the strengthening of the reaction at early time as gas concentrations increase and the $\mathrm{CO}_{2} / \mathrm{CO}$ ratio increases, indicating more complete oxidation. Second, they show that $\mathrm{CO}_{2}$ is the dominant combustion gas, which is as expected for a process dominated by oxidation. Finally, they indicate that gas concentrations diminish in the latter half of the tests; this is likely associated with the decreased oxygen mass flux (air velocity) at the front because the injected air is distributed over increasingly larger radii of influence. Moreover, in the shallow test they likely correlate to the little NAPL remaining to fuel the reaction when the reaction reaches the sheet pile wall, while in the deep test, the reaction reached the limits of the vapor collection system. The overall gas concentrations recovered in the deep test are approximately one-third to one-fifth those observed in the shallow test, reflecting the additional effects of dissolution in groundwater and dispersion processes that reduce the capture of those gases at the surface.

Figure 4 presents the TPH/EPH concentrations of all preand post-field-test soil samples collected from within the treatment areas for the shallow and deep field tests. TPH was reduced in the shallow test cell from a mean pre-test concentration of $37900 \mathrm{mg} / \mathrm{kg}(n=15, \mathrm{sd}=50800 \mathrm{mg} / \mathrm{kg})$ to a mean post-test concentration of $260 \mathrm{mg} / \mathrm{kg}(n=8$, sd $=185 \mathrm{mg} / \mathrm{kg}$ ) equating to an average remediation efficiency of 99.3\%. In the deep test, EPH was reduced from a mean pretest concentration of $18400 \mathrm{mg} / \mathrm{kg}(n=8, \mathrm{sd}=13400 \mathrm{mg} / \mathrm{kg})$ to a mean post-test concentration of $450 \mathrm{mg} / \mathrm{kg}(n=14, \mathrm{sd}=1100$ $\mathrm{mg} / \mathrm{kg}$ ) for an average remediation efficiency of $97.6 \%$. Posttest soil cores from both pilot tests (eight from the shallow test and nine from the deep test) from within the combustion zones indicated no visually apparent NAPL and visibly reduced moisture levels; this is consistent with the laboratory treatability test with site soils (representative photographs in Figure S4). The average concentrations given, and thus the remediation efficiencies presented, are representative for the locations sampled. The true averages are subject to some uncertainty due to heterogeneity, which is challenging to quantify at field sites. However, the nature of smoldering reactions, involving a causeand-effect relationship between combustion temperatures and NAPL removal, provides confidence that this level of treatment is continuous throughout the defined treatment zones (i.e., > $400{ }^{\circ} \mathrm{C}$ ) in Figure 2.

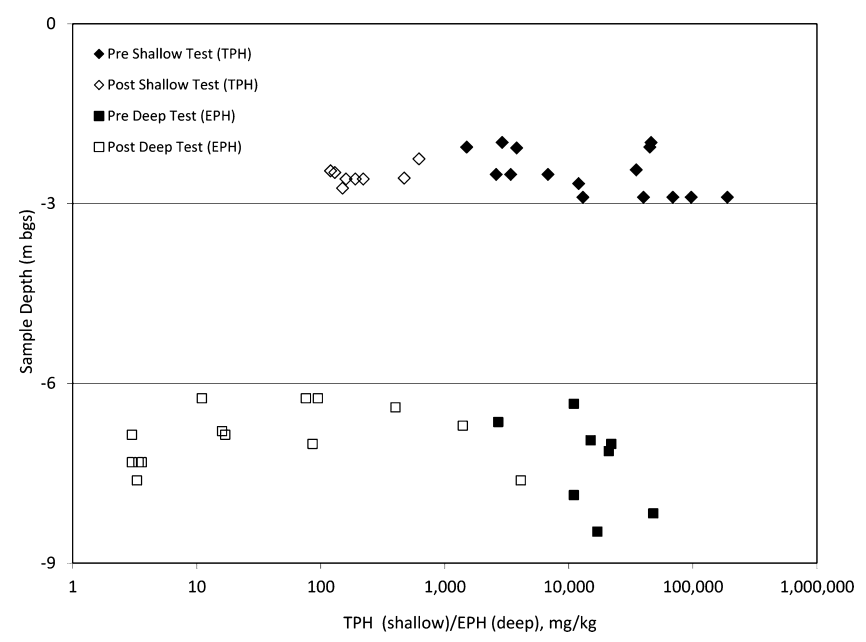

Figure 4. Pre- and post-TPH (shallow fill) and EPH (deep-sand) soil concentrations by sample depth. All post-test samples are collected from within inferred combustion zones. Note that the depth (vertical) axis is linear scale, and the soil concentration (horizontal) axis is logarithmic. Note that the uncertainty on TPH/EPH concentrations, based on the analytical method, is approximately $25 \%$.

For the shallow test, the total TPH mass removal rate in collected vapors was determined to be $0.22 \mathrm{~kg} / \mathrm{h}$ (Table S1); an in situ mass-destruction rate of $36 \mathrm{~kg} / \mathrm{h}$ was recorded at that time, yielding a DRE of $99.4 \%$. The mass-removal rate by volatilization in the deep test was calculated (average of two vapor samples) to be $0.12 \mathrm{~kg} / \mathrm{h}$ (Table S2); an average in situ mass-destruction rate of $5.55 \mathrm{~kg} / \mathrm{h}$ was recorded at that time, yielding a DRE of $97.8 \%$. The lower DRE for the deep test may reflect (1) less $\mathrm{CO}_{2}$ captured due to increased dissolution of $\mathrm{CO}_{2}$ in overlying groundwater or reduced capture efficiency (resulting in an underestimation of the mass destruction rate); (2) slightly different $\mathrm{CO}_{2} / \mathrm{CO}$ ratios corresponding to different peak temperatures, velocities, and other characteristics of the reaction at the two depths. These results are based on a total vapor sample for each test that was obtained when each reaction was strongest (peak air flow and peak heat generation) and thus represents an estimate for the self-sustaining portion of each test and may not accurately represent the volatilized fraction during the ignition (beginning) or extinction (ending) phases of the tests.

The energy for ignition in the deep test was estimated to be $1.1 \mathrm{~kJ} / \mathrm{kg}$ of soil remediated ( $3 \mathrm{~h}$ of heater operation followed by 10 days of self-sustained smoldering resulting in $44.5 \mathrm{~m}^{3}$ of soil remediated). Figure 5 presents energy for ignition values as a function of scale, comparing the deep test to ex situ coal-tar smoldering experiments conducted at a variety of scales by Switzer et al. $^{30}$ This plot reveals that the self-sustained smoldering reaction becomes increasingly efficient (i.e., less heat energy input per mass of soil remediated) with increasing scale of application. This behavior is expected because heat losses to the external environment are reduced with increasing scale, and the available radius of influence for a single ignition event increases substantially. ${ }^{33}$ The majority of thermal treatment methods utilize endothermic processes (e.g., volatilization) that require continuous energy input and thus the efficiency in terms of energy input is independent of the soil volume treated; for example, in situ thermal desorption typically requires between 300 and $700 \mathrm{~kJ} / \mathrm{kg}$ at the field scale. ${ }^{34}$ This ignores the energy input associated with the 


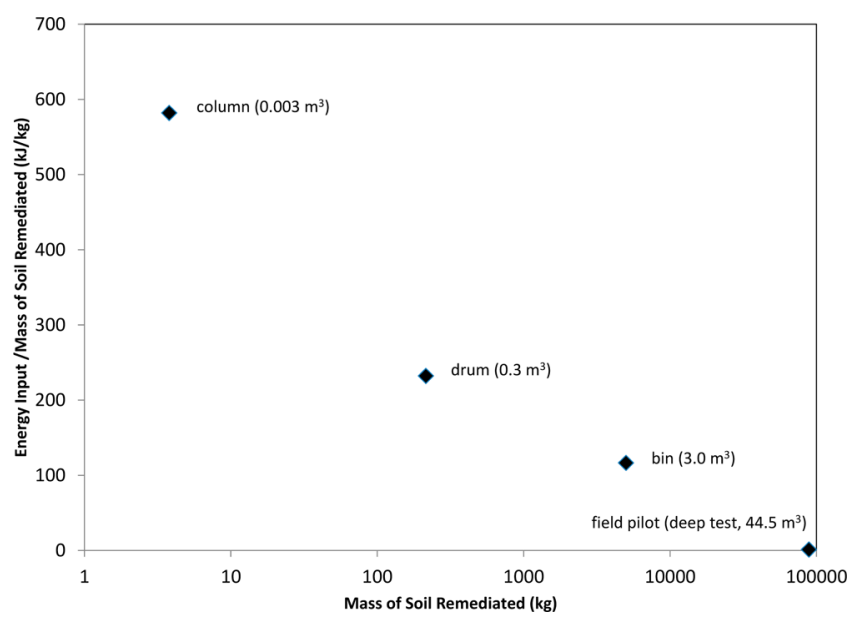

Figure 5. Energy for ignition for increasing scales of coal-tar smoldering experiments, demonstrating the increasing energy efficiency of the smoldering process with scale of application. Data from column-, drum-, and bin-scale ex situ experiments taken from Switzer et al. ${ }^{21}$ Note that the energy input (vertical) axis is linear-scale, and the mass of soil remediated (horizontal) axis is logarithmic.

infrastructure, such as vapor extraction and treatment, because these are similar for all thermal technologies. The energy efficiency of smoldering at the field scale, first hypothesized in bench-scale studies, ${ }^{14}$ is here quantified for the first time. Although the value of $1.1 \mathrm{~kJ} / \mathrm{kg}$ is a conservative estimate for the site, because the reaction in the deep test was artificially terminated, it is not expected that the log-linear relationship observed in Figure 5 will continue at much larger volumes. This energy efficiency value, and the corresponding $3.7 \mathrm{~m}$ radius of influence, represent suitable design parameters for applying STAR to the deep contamination at this site.

The shallow and deep tests described herein, the first-ever NAPL smoldering field tests, demonstrated ignition and propagation of a self-sustaining smoldering reaction in coaltar-contaminated soils in situ and below the water table. In situ destruction of coal tar was observed at rates up to $43 \mathrm{~kg} /$ hour resulting from a single ignition well, and smoldering fronts were found to propagate greater than $3.7 \mathrm{~m}$ from an ignition well at rates up to $1 \mathrm{~m}$ per day. No NAPL remained within defined treatment zones. In situ heterogeneity was observed to play a key role in the rate and uniformity of smoldering front spread because it strongly influences the velocity distribution of the air. Radius of influence may be affected by the pressure drop over distance through clean and dry soil (treatment zone), reduction in linear velocity of injected air with distance, and groundwater reinfiltrating the treated region between the air injection point and the combustion front. For the first time, it was demonstrated that field results were consistent with those from laboratory treatability tests with site soil. Mass removed through volatilization was determined to be on the order of 1 to $2 \%$ of the coal-tar mass destroyed in situ during smoldering. Petroleum hydrocarbon concentrations in treated soils were reduced on average by $98.5 \%$. These results provided the key information to design and implement a full-scale STAR remedy now being applied at the site.

\section{ASSOCIATED CONTENT}

\section{S Supporting Information}

The Supporting Information is available free of charge on the ACS Publications website at DOI: 10.1021/acs.est.5b03177.
Additional information on the method of estimation for the mass of destroyed coal tar. Images showing confidence contours of Kriged temperature values, shallow- and deep-test combustion gas concentrations, and soil photographs before and after STAR. Tables showing shallow- and deep-test VOC results. (PDF)

\section{AUTHOR INFORMATION}

\section{Corresponding Author}

*Tel: (519) 661-4154; fax: (519) 661-3942; e-mail: jgerhard@ uwo.ca.

\section{Notes}

The authors declare the following competing financial interest(s): Savron, the company who led the on-site activities, possesses the exclusive license to commercialize STAR.

\section{ACKNOWLEDGMENTS}

We are grateful to Paolo Pironi for his assistance and expertise throughout the project. Smoldering combustion of liquids for remediation is patented by the University of Edinburgh (International PCT Filing PCT/GB2006/004591, Granted Patents US 8,132,987 B2, AU 2006323431 B9, JP4 934832, CA 2,632,710, and PRC ZL20068005254.X) and Geosyntec Consultants Ltd. (International PCT Filing PCT/US12/ 35248).

\section{REFERENCES}

(1) Kueper, B. H.; Davies, K. Assessment and Delineation of DNAPL Source Zones at Hazardous Waste Sites; United States Environmental Protection Agency: Cincinnati, OH, 2009.

(2) DNAPL Site Characterization for Waste Management at Manufactured Gas Plant (MGP) Sites; Electrical Power Research Institute: Palo Alto, CA, 2004.

(3) Pankow, J. F.; Cherry, J. A. Dense Chlorinated Solvents and Other DNAPLs in Ground Water; Waterloo Press: Portland, OR, 1996.

(4) Gaylor, D. W.; Culp, S. J.; Goldstein, L. S.; Beland, F. A. Cancer Risk Estimation for Mixtures of Coal Tars and Benzo(a)pyrene. Risk Anal. 2000, 20 (1), 81-85.

(5) Health Effects Assessment for Coal Tars; United States Environmental Protection Agency: Washington, DC, 1984.

(6) Switzer, C.; Pironi, P.; Gerhard, J. I.; Rein, G.; Torero, J. L. SelfSustaining Smoldering Combustion: A Novel Remediation Process for Non-Aqueous-Phase Liquids in Porous Media. Environ. Sci. Technol. 2009, 43, 5871-5877.

(7) Gerhard, J. I.; Pang, T.; Kueper, B. H. Time Scales of DNAPL Migration in Sandy Aquifers Examined via Numerical Simulation. Groundwater 2007, 45 (2), 147-157.

(8) Birak, P. S.; Miller, C. T. Dense non-aqueous phase liquids at former manufactured gas plants: Challenges to modeling and remediation. J. Contam. Hydrol. 2009, 105, 81-98.

(9) Cerniglia, C. Aromatic hydrocarbons: metabolism by bacteria, fungi and algae. Toxicology 1981, 3, 321-361.

(10) Heron, G.; Parker, K.; Galligan, J.; Holmes, T. C. Thermal Treatment of Eight CVOC Source Zones to Near Nondetect Concentrations. Groundwater Monit. Rem. 2009, 29 (3), 56-65.

(11) Heron, G.; Carroll, S.; Nielsen, S. G. Full-Scale Removal of DNAPL Constituents Using Steam-Enhanced Extraction and Electrical Resistance Heating. Groundwater Monit. Rem. 2005, 25 (4), 92-107.

(12) Baker, R. S.; Bierschenk, J. M.; LaChance, J.; Heron, G.; Phelan, D.; Clock, J. A. In-Situ Thermal Treatment of MGP Waste and Creosote; www.terratherm.com/pdf/white\%20papers. [Accessed 15 February 2013].

(13) McGowan, T. F.; Greer, B. A.; Lawless, M. Thermal Treatment and non-Thermal Technologies for Remediation of Manufactured Gas Plant Sites. Waste Manage. 1996, 16 (8), 691-698. 
(14) Pironi, P.; Switzer, C.; Gerhard, J. I.; Rein, G.; Torero, J. L. SelfSustaining Smoldering Combustion for NAPL Remediation: Laboratory Evaluation of Process Sensitivity to Key Parameters. Environ. Sci. Technol. 2011, 45 (7), 2980-2986.

(15) Ohlemiller, T. J. Smoldering Combustion. In SFPE Handbook of Fire Protection Engineering ( $3^{\text {rd }}$ Edition); DiNenno, P., Drysdale, D., Beyler, C. L., Walton, W. D., National Fire Protection Association: Quincy, MA, 2002; 2/200-2/210.

(16) Drysdale, D. An Introduction to Fire Dynamics, $2^{\text {nd }}$ Edition; John Wiley and Sons Ltd., New York, 1998.

(17) Palmer, K. N. Smouldering Combustion in Dusts and Fibrous Materials. Combust. Flame 1957, 1 (2), 129-154.

(18) Torero, J. L.; Fernandez-Pello, A. C. Forward smolder of polyurethane foam in a forced air flow. Combust. Flame 1996, 106 (12), 89-109.

(19) Rein, G. Smouldering Combustion Phenomena in Science and Technology. International Review of Chemical Engineering 2009, 106 (1-2), 1957-1964.

(20) Pironi, P.; Switzer, C.; Gerhard, J. I.; Rein, G.; Torero, J. L.; Fuentes, A. Small-Scale Forward Smouldering Experiments for Remediation of Coal Tar in Inert Media. Proc. Combust. Inst. 2009, 32 (2), 1957-1964.

(21) Bar-Ilan, C. A.; Rein, G.; Walther, D. C.; Fernandez-Pello, A. C.; Torero, J. L.; Urban, D. L. The effect of Buoyancy on Opposed Smoldering. Combust. Sci. Technol. 2004, 176 (12), 2027-2055.

(22) Fatehi, D.; Kaviany, M. Adiabatic reverse combustion in a packed bed. Combust. Flame 1994, 99 (1), 1-17.

(23) Porteiro, E. J.; Patiño, D.; Miguez, J. L.; Granada, E.; Moran, J.; Collazo, J. Study of the reaction front thickness in a counter-current fixed-bed combustor of a pelletised biomass. Combust. Flame 2012, 159 (3), 1296-1302.

(24) Rogers, F.; Ohlemiller, T. J. Smolder Characteristics of Flexible Polyurethane Foams. J. Fire. Flammability 1980, 11 (1), 32-44.

(25) Wang, G. J. H.; Chao, C. Y. H.; Kong, W. Experimental study and asymptotic analysis of horizontally forced forward smoldering combustion. Combust. Flame 2003, 135 (4), 405-419.

(26) Anderson, M. K.; Sleight, R. T.; Torero, J. L. Downward smolder of polyurethane foam: ignition signatures. Fire Saf. J. 2000, 35 (2000), 131-147.

(27) Xia, T. X.; Greaves, M.; Turta, A. T.; Ayasse, C. THAI- A 'Shortdistance Displacement' In Situ Combustion Process for the Recovery and Upgrading of Heavy Oil. Chem. Eng. Res. Des. 2003, 81 (3), 295304.

(28) Garon, B. B. A. M.; Geisbrecht, R. A.; Lowry, W. E. Scaled model experiments of fireflooding in tar sands. JPT, J. Pet. Technol. 1982, 34 (9), 2158-2166.

(29) Hasan, T.; Gerhard, J. I.; Hadden, R.; Rein, G. Self-sustaining smouldering combustion of coal tar for the remediation of contaminated sand: Two-dimensional experiments and computational simulations. Fuel 2015, 150, 288-297.

(30) Switzer, C.; Pironi, P.; Gerhard, J. I.; Torero, J. L.; Rein, G. Volumetric scale-up of smouldering remediation of contaminated soils. J. Hazard. Mater. 2014, 268, 51-60.

(31) Scholes, G. C. Ignition Method Development and First Field Demonstration of In Situ Smouldering Remediation. M.E.Sc. Dissertation, University of Western Ontario, London, ON, 2013.

(32) Mann, H.; Whitney, D. On a Test of Whether One of Two Random Variables is Stochastically Larger than the Other. Ann. Math. Stat. 1947, 18 (1), 50-60.

(33) Bar-Ilan, A.; Putzeys, O. M.; Rein, G.; Fernandez-Pello, A. C.; Urban, D. L. Transition smoldering to flaming in small polyurethane foam samples. Proc. Combust. Inst. 2005, 30 (2), 2295-2302.

(34) Triplett Kingston, J. L.; Johnson, P. C.; Kueper, B. H.; Mumford, K. G. In Situ Thermal Treatment of Chlorinated Solvent Source Zones. In Chlor. Solv. Source. Zone. Rem.; Springer, New York, 2014, 527. 